\title{
EU BETWEEN OLD AND NEW SECURITY STRATEGIES APPROACH
}

\author{
Goran ZENDELOVSKI, PhD \\ Faculty of Philosophy - Institute of Security, Defense and Peace \\ E-mail: goranz@fzf.ukim.edu.mk
}

\begin{abstract}
In 2003 the European security strategy named A Secure Europe in a Better World was adopted. Since then, the security environment changed radically and the perception of security is different than before. The forces that prompted the changes are a result of the dynamics of contemporary globalization that has managed to reshape space, sovereignty and power. These changes bring with them new and often, unpredictable risks and hazards that increased in intensity and time. The global interconnectedness and interdependence between countries and peoples have contributed to greater mobility of tourists, terrorists, students and refugees.

Over the past decade the European Union has faced numerous crises and turmoil which indirectly/directly affected its stability and prosperity. From conflicts in Africa, security tensions in Asia, economic crisis, climate change, supply of natural resources, partnerships and expansions, the stability of the Western Balkans, refugee crises to terrorist attacks by non-state actors. These complex events led to tensions and divisions within the Union and beyond, the same were a prelude to reforms of the existing security strategy. A moment of rethinking the new content will interact with the current and future political-security and economic-social environment. Through analysis of the old-new strategic documents in the area of security will acknowledge the extent to which the European Union has evolved. The focus is directed towards the questions whether the "old Europe" is prepared for the new security challenges, and whether strategic goals and principles correspond to the real situation in Europe and the world?
\end{abstract}




\section{Securianues}

Key words: European Union, Challenges and Opportunities, Security Strategies, Global Player.

\section{Introduction}

In May 2003 EU High Representative for the Common Foreign and Security Policy (CFSP), Javier Solana, presented the draft of the European Security Strategy (ESS). The same year, the European Union adopted its first security strategy entitled as A Secure Europe in a Better World. The document was passed when the Global War on Terrorism (GWOT) had already started, as well as the interventions in Afghanistan and Iraq. The European security strategy begins with the sentence "Europe has never been so prosperous, so secure nor so free" (European Security Strategy, 2003). But by 2003 Europe and the world had changed dramatically, and the arguments and attitudes within the strategy do not match the current security environment. It was necessary to devise new content and conceptual approach that will cover the current and future events, whereas the commitments in the document should be operational for effectively addressing current and future security challenges and threats. The strategy should set priorities that are prerequisite to start the next stages and cycles of restructuring. Because of the very complex and variable security content, major adjustments are not eligible, yet possible if there are substantial changes in international relations as well as the part involving challenges, risks and threats (Нацев, 2006: 461- 477).

The main arguments that the European Security Strategy relies on are outdated, been changed foreign policy priorities of the Union, security environment, threats and dangers, interests and objectives of the member states, the transatlantic partnership, the position and role of the EU on the international stage.

Five years after the adoption of the strategic document of the EU, it has been revised, i.e. a Report on the Implementation of the European Security Strategy has been presented, under the title Providing Security in a Changing World that aimed at evaluating the ESS. The report outlines how the strategy has worked in practice and in which segments it needs to improve. It also states that, "the EU has made substantial progress over the last five years, and already contributes to a more secure world" (Report on the Implementation of the European Security Strategy, 2008). It has contributed to human security, reducing poverty and inequality, promoting good 


\section{Seccurity}

governance and human rights, and preventing conflict. It also highlights the experience and capabilities of the Union in the field of common foreign and security policy by participating in 30 civilian and military missions. However, it did not offer new guidelines but rather confirmed the "achievements" and "lessons learned" from past years, stressing that the EU should be "more capable, more coherent and more active" (Report on the Implementation of the European Security Strategy, 2008: 2).

This raises the question whether the EU needs a new security strategy, and which segments of the strategy should be changed? The opinions and answers were different, which may be divided into several categories. The first category includes those representatives of the Member States countries that considered that the strategy is outdated and needs to draft a new document. The second category covers those countries that were concerned with "local policies" and are not interested in broader strategic changes. While as the third category addresses the member states of the Union, whose representatives believed that no need for a new security strategy, because "the strategic gap" is filled with new documents on security.

In this context, former High Representative of the Union for Foreign Affairs \& Security Policy/Vice-President of the European Commission, Catherine Ashton, pointed out that the adoption of several security documents are "complemented" the European Security Strategy (Drent and Landman, 2012: 4). This involves the implementation of individual sub-strategies in the field of security and beyond that work on certain segments of the ESS. The following sub-strategies are included: The EU Strategy against the Proliferation of Weapons of Mass Destruction (2003), The Strategy for the External dimension of Justice and Home Affairs (2005), Counter Terrorism Strategy (2005), Strategy to combat illicit accumulation and trafficking of SALW and their ammunition (2006), Strategy for a Secure Information Society (2006), Energy 2020-A Strategy for Competitive, Sustainable and Secure Energy (2010), Internal Security Strategy (2010) and Cyber Security Strategy of the European Union (2013). However, the new wave of changes in international relations, contributed to re- actualizing the issue of a new security strategy among European senior officials. In July 2012, the foreign ministers of Italy, Poland, Spain and Sweden suggested ideas for making the European global strategy (Lundin, 2012: 3). While, the High Representative of the European Union for Foreign Affairs and Security Policy, Federica Mogherini, pointed out that "The European Union has all the means to be an influential global player in the future - if it acts together. We need a common, comprehensive and consistent EU 


\section{Secururity}

global strategy" (Global Strategy to steer EU external action in an increasingly connected, contested and complex world, 2015; Annegret and Kaim, 2015).

\section{Why EU needs a new strategic approach}

More than a decade ago, the EU leaders adopted the European security strategy. Since then there are many reasons why Europe needs a new security strategy. First, the causes that result from the changes within the Union need to be identified, and those reasons that originate outside the EU space need to be analyzed.

Internal changes relate to the process of territorial expansion of the EU. The European Union focused on geographical expansion, which allowed it to grow into a competitive force on the global stage. Since 2003 the number of EU member countries has increased from 15 to 28 countries with over 503 million inhabitants, representing $7 \%$ of the world population, and realizing a total production of $30 \%$ of the world economy (World Economic Outlook, 2015). However, taking into account the phases of the EU enlargement $(2004,2007$, and 2013) concluded that half of the current member states were not involved in the creation of the European security strategy at all. Meanwhile the document emphasized the unification of countries "as a union of 25 states" which have not been official member states, predicted to become a global player (European Security Strategy, 2003: 1). However, an attempt was made to overcome the divisions between "old" and "new" Europe.

But developments outside the European Union contributed to a different approach in the area of security. The EU looked at security in a globalistic sense or as emphasized in the Report on the Implementation of the ESS, "Globalization has brought new opportunities, but globalization has also made threats more complex and interconnected" (Report on the Implementation of the European Security Strategy, 2008). So the new strategy should take into account the security environment, global challenges and key threats, which will affect the achievement of the strategic objectives of the EU. Therefore strategic objectives in the document must be reformulated or supplemented, and they relate to: (a) Addressing the threats; (b) building security area around Europe and $(c)$ strengthening the international order based on effective multilateralism (European Security Strategy, 2003: 6-10; Гоцевски и други, 2007: 127). 


\section{Seccurity}

Addressing the threats. The focus of Europe aims at transnational threats such as terrorism, proliferation of weapons of mass destruction, regional conflicts, state failure and organized crime. But globalization processes contributed to the internationalization of risks and threats have increased in intensity, space and time. Since 2003, the number of macro terrorist attacks has increased in the world and Europe. The attacks in Madrid, London, Brussels and Paris, indicate that the EU is very vulnerable in its territory. The latest crises and conflicts in the Middle East and North Africa are growing. The number of decaying states gravitating around Europe is increasing.

It is obvious that attitudes in the European Security Strategy were aimed at immediate risks and threats, not towards future threats. Therefore, in addition to the security strategy, the Union has adopted the following strategic documents: EU Strategy against the Proliferation of Weapons of Mass Destruction, The Strategy for the External dimension of Justice and Home Affairs, Counter Terrorism Strategy, Internal Security Strategy and Cyber Security Strategy. These documents complement the concept of security in modern conditions whose focus is on economic, societal, environmental and information security. This means that apart from the usual threats Europe faces new security risks and dangers produced by living standards, the impact of the financial crisis, energy insecurity, climate change and immigration (Dennison and Associates, 2013).

Building security area around Europe. The strategy emphasizes that "the first line of defense will often be abroad" (European Security Strategy, 2003: 6). The EU needs to involve earlier, before the crisis emerges. It refers to Eastern Europe and the Mediterranean area countries, but the EU remains to address the problems and developments in the Balkans, South Caucasus, Ukraine and Moldova in the future.

However, with the new geographic expansion, the EU faced a number of difficulties in securing its territory. Many countries border it and this creates additional problems in dealing with new risks and threats. For example, United States borders with only two countries (Canada and Mexico). Hence, the degree of EU security, through the prism of geographical aspects, will depend on developments in the immediate environment such as Eastern Europe, North Africa and Middle East.

In this context, the question arises whether the EU would be able to deal simultaneously with multiple security challenges and threats coming from neighboring countries? Integration processes have increased the level of security in the EU, but also 


\section{Seccurity}

brought the Union closer to critical areas. Some neighboring countries are valid for weak states that cannot establish control over its territory, nor can cope with security challenges. The problems of these countries, such as political instability, violent conflicts, extremism and terrorism, organized crime, refugees and humanitarian crises affected the European security and stability (Drent and Landman, 2012).

In order to reduce the challenges and threats from the neighbors, it implemented the European Neighborhood Policy (ENP) in 2004. The ENP includes the promotion of democracy, rule of law, strengthening of trade relations and helped in the reform of the eastern and southern neighbors. But, after ten years, the dramatic changes in geography, politics, economics and security, contributed to the review of the European policy towards its neighbours. Today, ENP includes sixteen countries (Algeria, Armenia, Azerbaijan, Belarus, Egypt, Georgia, Israel, Jordan, Lebanon, Libya, Moldova, Morocco, Palestine, Syria, Tunisia, and Ukraine) from the Middle East, North Africa and Eastern Europe, which gravitate around the Union (Lehne, 2014).

Compared to the past, these regions are far from politics to bring them closer to the Union. They have fragmented and are becoming unstable, and their political and economic transition has been disabled. In the south, the Arab Spring (2011) did not lead to a democratic transformation of the Middle East and North Africa, but to the unrest and clashes on a large scale. Military intervention on Libya (2011) and the civil war in Syria (which is ongoing) destabilized the entire region. Mass migrations of these risky countries to the EU have contributed to disruption of the level of security and stability in Europe. In the East, the crisis in Ukraine (2014), received enormous proportions when Russia annexed Crimea, which contributed to greater tension between the EU and Russia. Also, the countries of the Western Balkans (applies to Kosovo, Bosnia and Macedonia, where the EU had several civilian and military operations) are still politically unstable, and are triggering new security problems.

These events show that the European Union is still far from using its instruments to improve the security environment. Because the new security document should clearly emphasize what are "the zones of stability" and "the zones of crisis and instability". Then, countries and regions, which are a major threat to Europe, should be emphasized, how Europe will deal with them, what instruments it would use in the event of crises and dangers outside its territory.

Strengthening the International order based on Effective Multilateralism. The strategy emphasizes the respect for international law and cooperation with 


\section{Seccurity}

international organizations such as the UN, IMF and World Bank crucial to strengthening the international order. Hence, the EU is ready to share the burden and responsibility for global security and building a better world. It sees solutions through the creation of an international order based on effective multilateralism in which other regional organizations such as ASEAN, MERCOSUR and the African Union will participate (European Security Strategy, 2003: 9).

Geopolitical turbulence led to a change of power in international relations and disrupting the balance between the actors. Besides the states, the world order consists of other non-state actors who have different interests and purposes. Mutual rivalries are expected to increase that will lead to making the world a less cooperative place. Because of this, we believe that the EU should move in another direction. In the past decade, the international system has moved from multilateral engagements to a multipolar system, in which multilateralism is increasingly marginalized. We consider it necessary to rethink and consider whether effective multilateralism is adequate or needs to be reviewed, or if a new concept needs to possibly be developed (Drent and Landman, 2012).

\section{The EU's new strategic approach}

In 2016 High Representative Federica Mogherini presented the Global Strategy for the European Union's Foreign and Security Policy (EUGS) to the European Council. In the "Global Strategy" are presented ambition for a stronger Europe, fundamental interests, principles and priorities of the EU's engagement in the world. It relies on peace and security, prosperity, democracy and the rules-based global order (with multilateralism as its key principle) as vital interests for external action. Preservation of peace and security of its citizens and territory are of crucial importance for the Union, and the correlation between internal and external security means "broader interest in preventing conflict, promoting human security, addressing the root causes of instability and working towards a safer world". Despite interests, the European Union will be guided by the principles of "realistic assessment of the strategic environment" and "idealistic aspiration". The solution between isolationism and interventionism, the EU will see through the prism of "principled pragmatism", as a new approach to foreign 
and security policy (A Global Strategy for the European Union's Foreign and Security Policy, 2016).

Union calls for the principles of unity, ("In a more complex world, we must stand united"), engagement ("In a more connected world, the EU will engage with others"), responsibility ("In a more contested world, the EU will be guided by a strong sense of responsibility") and partnership ("investing in our partnerships" with states, regional bodies, international organisations, civil society and private sector).

There are dilemmas and obscurities about whether the EU will focus more on pragmatic objectives or to its ideals. While the global actors apply the Machiavellian version in foreign and security policy, Europe will focus on realization of the interests through the prism of "Realpolitics with European characteristics" (Biscop, 2016). In terms of EU unity are emphasized that "there is no clash between national and European interests". This principle does not reflect the real situation in the EU, because only a few days before being adopted the "Global Strategy", the United Kingdom (through a referendum) decided to leave the EU. In addition, it is obvious dominance of a few countries whose national security policies are promoted as strategic objectives of the Union, and still are not exceeded the tensions between the national interests of the member states, as well as between the roles which are the EU has as a regional and global power and transatlantic partner (Dennison and Associates, 2013).

From the past experience, we have seen how certain countries (e.g. The Big Three - France, Germany and the United Kingdom), decided among themselves for following directions of EU's development, holding aside other member states. The Big Three is the one that influenced on the common foreign and security policy, and making it the most represented in decision-making in international institutions and organisations such as the UN, NATO, the World Bank, IMF, G7 and the G2O.

In order to promote its interests, and also to hold on to its principles, the European Union will strive towards achieving the following priorities: (1)The Security of our Union; (2) State and Societal Resilience to our East and South; (3) An Integrated Approach to Conflicts; (4) Cooperative Regional Orders and (5) Global Governance for the 21st Century.

(1) The Security of our Union. In the introduction of the Strategy is said "we need a stronger Europe. We live in times of existential crisis, within and beyond the European Union. Our Union is under threat. Our European project, which has brought unprecedented peace, prosperity and democracy, is being questioned" (A Global 


\section{Seccurity}

Strategy for the European Union's Foreign and Security Policy, 2016: 13).The Europe suggests necessary of strengthening of the security and defense capabilities and use of combined policies (soft and hard power) and tools for effective action in the field of energy security, migration, climate change, terrorism and hybrid threats. It will try through five lines of action - Security and Defense, Counter-terrorism, Cyber Security, Energy Security and Strategic Communication to strengthen its security and to participate in collective security and defense.

But due the refugee crisis, the Union faces the threats of terrorism, a resurgence of nationalism and anti-European views, collapse of the Schengen area and disintegration of the Union. Refugee crisis (which is the largest since World War II), contributed the main focus of the EU to be directed towards countries - transit of migrants and refugees (countries from Western Balkan and Turkey). In 2015 more than a million refugees and migrants arrived in Europe (Munich Security Report, 2016: 40), and as a result of that, the same year the number of victims from terrorist attacks (in the countries of the $0 E C D$, which includes 25 European countries), rising by 650 per cent when compared to 2014 (Global Terrorism Index, 2016). Furthermore, radical and eurosceptic parties might be a reason to undermine the unity of the West and could lead to fragmentation of the European Union. The processes of disintegration could eliminate Europe as a competitive actor of the international scene.

(2) State and Societal Resilience to our East and South. As well as in past years, the vulnerability of the Union comes from outside its borders. In order to deal with the threats, EU is prepared to invest in strengthening security in the countries and societies of its surrounding regions. Through the policies of enlargement, European Neighborhood Policy (ENP) and Effective Migration Policy would deal easier with the challenges and dangers of migration, terrorism and organized crime.

(3) An Integrated Approach to Conflicts. Multi-dimensional approach and the use of different policies and tools will help the Union in conflict prevention. European "comprehensive approach" refers to the participation in all stages of the conflict cycle, and implementation of "multi-lateral approach", which would involve all those players present in conflict. EU plans to respond rapidly, responsibly and decisively in case of crises. Especially in the fight against terrorism, it will rely on its security and defense capabilities (A Global Strategy for the European Union's Foreign and Security Policy, 2016). 


\section{Seccurity}

But the crises from Greece to Ukraine, the collapse of countries from Libya to Iraq and the war in Syria were the cause of dysfunction of the EU and other international organizations in crisis situations. In particular the Union was not effective in the prevention from terrorism at home.

(4) Cooperative Regional Orders. Europe will promote cooperative regional orders, which represents a mix of bilateral, sub-regional, regional and inter-regional relations. In order to preserve European security order and peace will be driven by specific goals in different parts of the world. The European Union will advocate for improving relations with Russia which are still of crucial strategic importance for European security order. The EU will apply multilateral cooperation for a peaceful and prosperous Mediterranean, Middle East and Africa and will continue to strengthening the transatlantic partnership with the United States and Canada through the NATO. In the strategy are emphasizes the direct connection between the European prosperity and Asian security. Trade relationship with China will be a priority for the Union and its relations with other strategic partners and organizations, such as Japan, India, ASEAN and Mercosur.

Analyzed from an economic perspective, these countries are crucial for the European economy, China and India are the Union's largest trading partners, while Japan and Indonesia are on the third and fourth position. Over the past two decades, China has managed to rescue 600 million people out of poverty and by 2030 its gross domestic product is expected to represent $20 \%$ of world GDP, exceeding the EU and the USA. Next is India, which by 2030 will reach about $16 \%$ of world GDP (The European Union in a changing global environment: A more connected, contested and complex world, 2015: 9).

We can conclude that the priorities of the Union are unchanged and almost identical with the priorities of the Security Strategy from 2003. However, current developments about tension in relationship between the East and West, leaves a scope for establishing new international organizations who may advocated a more equal relationship and involvement of other countries from the world. In this regard the countries of the group BRICS will endeavor to create a parallel security and economic institutions as a possible alternative to the existing western international organizations. In the longer term, the BRICS countries will seek to reduce the impact of the West within the existing global institutions, NATO, the IMF and the World Bank. In this case the EU could be find itself between the "hammer and the anvil" because cooperation 


\section{Seccurity}

with new partners from the East could bring confrontation with allies from the West (Dennison and Associates, 2013).

(5) Global Governance for the $2 P^{\text {tt }}$ Century. The European Union will continue to advocate for "a strong UN as the bedrock of the multilateral rules-based order" and involvement of international and regional organizations as well as state and non-state actors in the global order. The EU strives for reforming the Security Council of the UN and international financial institutions, and will strive for a united representation of the euro zone within these institutions.

European representative Federica Mogherini points out that "this is no time for global policemen and lone warriors", which means that the EU will promote international system based on multilateralism. The realization of its foreign and security policy will be viewed through the prism of connection with old and new players on the global stage and discovering new formats for cooperation. EU will invest in so-called "win - win" solutions, leaving the illusion that the international politics can be a "zero sum" game (A Clobal Strategy for the European Union's Foreign and Security Policy, 2016: 4).

\section{The EU as a Global Player - from vision to action}

The EU Global Strategy has a very ambitious approach to external security action. In the current period of transition and reform in the EU, the issues are how much will be able to realize its ambitions spread on several continents and be effective in addressing issues of different political, economic, social, security and defense character?

By promoting the concept of "soft power", The European Union managed to gain international credibility and strengthen its international position. With its developed and widespread economic platform, a trade association and integration it tended to be a strong actor on the global stage. However, strong competition in the world weakened "the European soft power" and contributed to shifting the global strategic epicenter towards Asia. This shows that the Union needs an urgent transformation of its foreign policy if it desires to be a global actor. It will have to change its strategic priorities and to broaden the agenda with new strategic partners who will play an important role on the international scene in the coming years. 


\section{Seccurity}

"Civilian power" of Europe is not enough for global influence and not operates with reality in this insecure and unstable world. Therefore, it is ready to invest in all areas of foreign policy, especially in the field of hard power - security and defense. Hard power of the EU is crucial for European autonomy for external action, and to climb on a better position on the international security scene. The European Union should be more flexible and to make certain changes in three areas - diplomacy, common foreign and security policy and development.

That is necessary, because Europe is more fragile and less secure than in 2003. The changes in external strategic environment and within the Union, as well as the abandonment of one of the three largest and most important countries of the Union, United Kingdom, will prevent the realization of the European vision and ambition into action. Because, the United Kingdom is an impressive diplomatic power, the fifth most powerful economic and fifth military power in the world. Brexit will reduce the EU's credibility globally, especially in the CSDP. The EU and UK are the largest trade partners, more than $80 \%$ of British companies have trade relations with the $\mathrm{EU}$, and also UK is one of the most popular destinations for Chinese investment in Europe (National Security Strategy and Strategic Defence and Security Review of the UK, 2015: 53, 71). While in the European defense budget, United Kingdom participates with even 21.4\%. (SIPRI, Military Expenditure Database, 2011). In addition, in the middle between the EU and the UK are the USA, which is strategic partner in security, defence, foreign policy and the economy, and a major actor in NATO. These indicators show that there is a possibility of disturbing the European security compactness and strategic autonomy of the Union in international relations.

In the last part of the Strategy states that from this document should produce several sub strategies which will be in the context with political priorities and goals of the Union. The purpose of individual strategies is to determine the civil-military spectrum, tasks, needs, opportunities, priorities and deadlines for review of existing strategies. The EU Global Strategy will strive for periodically reviewing and consultation with the Council, Commission and European Parliament. Hence, the European Union provides a complement to "strategic gap" and stressing its next steps as a regional and global power. In October 2016, the EU Council adopted the strategic priorities for implementing the EUCS for 2016-2017, focusing on five priority areas for the external action of the EU: (1) Security and Defence; (2) Resilience building and integrated approach to conflict and crises; (3) Strengthening the nexus between internal and 


\section{Securiagues}

external policies; (4) Updating existing or preparing new regional and thematic strategies and (5) Stepping up public diplomacy efforts (Council conclusions on the global strategy on the EU's foreign and security policy, 2016).

The next step on the EU was in November 2016, when by the High Representative of the Union for Foreign Affairs and Security Policy, was presented Implementation Plan on Security and Defence. This Implementation Plan on Security and Defence is calling on the EU to be a credible actor in security and defense spheres. According to the Plan, the European Union will contribute to: (a) responding to external conflicts and crises; (b) building the capacities of partners, and (c) protecting the Union and its citizens (Implementation Plan on Security and Defence, 2016). The Plan is part of a broader package that includes workout of additional documents in this sphere. At the same period, the European Commission adopted the European Defence Action Plan (EDAP), which is closely related to the Implementation Plan on Security and Defence and EU-NATO Joint Declaration. EDAP is focusing on strengthening the European defense policy and investing in defense capabilities as well as improving European strategic autonomy and strengthening its ability to acting together with partners. For that purpose, was adopted the EU-NATO Joint Declaration in Warsaw (2016) which gives strong impetus to the strategic partnership between NATO and the EU in security and defense spheres.

The cooperation in the defense sector is a strategic priority of the EU. The future plans of Europe are aimed at building a robust defense capabilities with which can be a global player. In European Defence Action Plan underlines that Europe in the area of defense is behind its partners. The European Union from 2005 to 2015 had a decline in defense spending by about $11 \%$, and has an annual budget of 200 billion euros on defense (European Defence Action Plan, 2016:4). According to future projections (up to 2020) the Union Defense is expected to allocate around 147 billion euros (Ballester, 2013). Opposed to the EU, the United States in 2015 invested more than twice in defense, and China has increased its defense budget by $150 \%$ in the past decade. In 2015, Russia has invested 5.4\% of its GDP in defence (European Defence Action Plan, 2016).

These financial projections of the European Union are not sufficient for it to be a "super power". From the foregoing, it is evident that the European strategic identity will depend on developments in Asia. Therefore, in the European security strategy, which is also the main instrument for the implementation of the common foreign and 


\section{Seccurity}

security policy should explain how it will engage in relations with new actors and organizations. So far, the position of the Union was like that one of the non-aligned countries, to be among the great powers, a closer partner to one side, and more or less autonomous to other participants (Drent and Landman, 2012: 2). But if it wants to be a competitive force, it is necessary to strengthen (in financial terms), Common Foreign and Security Policy (CFSP), which is a fundamental pillar for achieving the EU as a global player. The EU budget for CFSP increased from 285 million euros in 2008 to 396 million euros in 2013. However, according to future projections, the Union plans to cut down the figure of 354 million euros by 2020 (Yearbook of European Security, 2014: 55, $57,68)$.

According to these indicators, the process of demilitarization of Europe is real, and the negative trend in the financing of the common foreign and security policy will continue in the next few years. Doing so will reduce the possibilities of the EU to be the next superpower that will have greater engagement in international affairs.

This steps which provides Global Strategy for Foreign and Security Policy exceeds the flaws that had The European Security Strategy from 2003, which lacked "strategic upgrading". We emphasized that constant revision of security documents is not necessary, but any delay would reflect on the internal and external security policy. Seen through the prism of "strategic updating" of strategic documents, the European Union is in a worse situation than its allies. In comparison to the EU, the United States has revised its National Security Strategy (2002, 2006, 2010 and 2015.) in a relatively short time. The new strategic document of the European Union has clear plans for implementation of the European strategic objectives and priorities. Is needed a small caution and modesty in ambitions related to security and defense issues, which are highly sensitive during crises, instability and polarization in the policies and interests of the EU Member States.

\section{Conclusion}

In the past twenty years the European Union's contribution was enormous. Its model of integration and interaction is an example for several regions in the world. But today, Europe is facing a deep crisis that could easily disrupt its cohesion. The dynamic processes of the globalization that have brought new risks and dangers to the "door" of 


\section{Securianues}

Europe, question the European security and stability. Rapid changes in the security environment compelled the Union to make a full scan and analysis of the possible consequences for its security.

For this purpose the Union was forced to adopt a global strategy for foreign and security policy. While the intentions in the document is too ambitious, however, correspond with real situation, interests, needs, opportunities and capacities for the implementation of the common foreign and security policy of the European Union. The lessons learned and past experiences are implemented in the Strategy, as well as future steps and plans for external action of the EU.

\section{REFERENCES:}

1. A Secure Europe in a Better World. European Security Strategy. (2003) [pdf] Brussels: European Council. Available at :https://www.consilium.europa.eu /uedocs/ cmsUpload/78367.pdf [Accessed June 2004].

2. Annegret, B. and Kaim, M. (2015) New European Security Strategy - The Transatlantic Factor. German Institute for International and Security Affairs.

3. Ballester, B. (2013) The Cost of Non-Europe in European Common Security and Defence Policy. European Added Value Unit, European Union. Available at: http://www.europarl.europa.eu/RegData/etudes/etudes/ join/2013/ 494466 /IPOL-JOIN_ET\%282013\% 29494466_EN.pdf [Accessed 5 May 2014].

4. Biscop, S. (2016) "The EU Global Strategy: Realpolitik with European Characteristics". Security Policy Brief, No. 75.

5. China defence spending to double by 2020. (2015):.[online] Available at :http://cnbc.com /2015 /09 /02/china-defence-spending-to-double-by-2020 [Accessed 26 Nov.2015].

6. Dennison, S., et al. (2013) Why Europe needs a new global strategy. [pdf] European Council on Foreign Relations. Available at :https://www.ecfr.eu. [Accessed 5 May 2015].

7. Drent, M., and Landman L. (2012) Why Europe needs a new European Security Strategy. The Clingendael Institute, [online] No.9, Available at: http://www. clingendael.nl/sites/default/files/20120706_research_ policybrief9_llandman_mdrent.pdf [Accessed 1 June 2014]. 


\section{Securiagues rity}

8. European Defence Action Plan. (2016) European Commission. Brussels.

9. EU-NATO Joint Declaration. (2016) Warsaw.

10. Global Strategy to steer EU external action in an increasingly connected, contested and complex world. [online] Available at:http://www.eeas.europa. eu/top_stories/2015/150627_eu_global_strategy_en.htm [Accessed 5 Dec. 2015].

11. Global Terrorism Index. (2016) Institute for Economics and Peace.

12. Гоцевски, Т. Бакрески, 0., и Славески, С . (2007) Европската унија низ призмата на европската безбедност. Скопје: Филозофски факултет.

13. Implementation Plan on Security and Defence. (2016) Council of the European Union. Brussels.

14. Kissinger, H. (2002) Does America need a Foreign Policy? Toward a Diplomacy for the $21^{\text {st }}$ Century. New York: Simon \& Schuster.

15. Lehne, S. (2014) "Time to Reset the European Neighborhood Policy". [online] Available at: http://carnegieeurope.eu/publications/?fa $=54420$ [Accessed 10 Oct. 2015].

16. Lehne, S. (2012) "The Big Three in EU Foreign Policy".[online] Available at : http:// carnegieeurope.eu/publications/?fa=48759\# [Accessed 10 Sep. 2015].

17. Lundin, L.E. (2012) From a European Security Strategy to a European Global Strategy: Ten Content-Related Issues. Swedish Institute of International Affairs, [online] No 11, Available at: http://www.ui.se/upl/files/76641.pdf [Accessed 10 0ct. 2015].

18. Military spending in Europe in the wake of the Ukraine crisis. (2015).[pdf] SIPRI. Available at :http://www.sipri.org/media/website-photos/milex-mediabackgrounder-2015 [Accessed 5 0ct. 2015].

19. Military Expenditure Database (2011). SIPRI.

20. Munich Security Report. (2016) Boundless Crises, Reckless Spoilers, Helpless Guardians, Munich Security Conference.

21. Нацев, 3. (2006) „Од стратегија до систем на национална безбедност и одбрана-приод и општи одредби". Годишен зборник 59, Филозофски факултет: 461-477.

22. National Security Strategy and Strategic Defence and Security Review of the UK. (2015) London. 
23. Report on the Implementation of the European Security Strategy - Providing Security in a Changing World. (2008) [pdf] Brussels: European Council. Available at :http://www.satcen.europa.eu/pdf_key/report \%20on\%20the\% 20implementation\% 20of\%20the\%20ess.pdf [Accessed 4 Mar. 2010].

24. Shared Vision, Common Action: A Stronger Europe - A Global Strategy for the European Union's Foreign and Security Policy. (2016) EU. Brussels.

25. Strategic Issues of European Security. (2014) [pdf] National Security Bureau. Available at: http://en.bbn.gov.pl/en/news/343,Strategic-Issues-of-EuropeanSecurity.html. [Accessed 7 Nov. 2015].

26. The European Union in a changing global environment:A more connected, contested and complex world.(2015) [pdf] Available at: http://eeas.europa.eu/ docs/strategic_review/eu-strategic-review_strategic_review_en.pdf. [Accessed 7 Nov. 2015].

27. Waever, O., Buzan, B., Kelstrup, M. and Lamaitre, P. (1993) Identity, Migration and The New Security Agenda in Europe. Pinter Publishers Ltd.

28. World Economic Outlook-Adjusting to Lower Commodity Prices.(2015) International Monetary Fund. Available at:http://www.imf.org /external /pubs /ft/weo/2015/02/pdf/text.pdf; http://europa.eu/about-eu/facts-figures/ economy/ index_en.htm. [Accessed 10 ct. 2015].

29. Yearbook of European Security (2014). [pdf] The European Union Institute for Security Studies. Available at:http://www.iss.europa.eu/uploads/media/ YES2014.pdf [Accessed 4 Nov. 2015]. 